\title{
Is the Inquiry Based Education Paradigm Useful not just for Teaching Sciences but also Theology?
}

\author{
1. Prof. Mihai A. GîRȚU, PhD \\ Department of Physics and Electronics \\ Ovidius University of Constanta \\ Constanța-900527, Romania \\ mihai.girtu@univ-ovidius.ro
}

\author{
2. Fr. Lecturer Cosmin Tudor ClOCAN, PhD \\ Department of Theology \\ Ovidius University of Constanta \\ Constanta-900527, Romania \\ cosmin.ciocan@univ-ovidius.ro
}

\begin{abstract}
Starting from the traditional approaches to teaching science and religion we discuss modern pedagogical methods based on inquiry. We explore whether and how the teaching methods specific to each discipline may benefit in the teaching of the other.
\end{abstract}

Keywords: science education, theology education, inquiry based learning

\section{INTRODUCTION}

A year ago we attempted to respond to the challenge posed by Dialogo 2014, the virtual conference on the dialogue between science and theology, discussing how diet impacts on health, as a case study of a wider debate on scientific consensus, public perceptions and religious beliefs [1]. Dialogo 2015 renews that challenge: can a scientist and a theologian find some common ground and address the same topic from their different perspectives? As we are both educators, we decided to concentrate this time on pedagogy, by discussing, comparing and contrasting the most effective methods of teaching science and theology. We start by reviewing the early approaches to teaching science and religion and then discuss the modern methods for each field, exploring whether and how they can be used for the other.

\section{TRADITIONAL APPROACHES TO TEACHING}

\section{SCIENCE AND RELIGION}

Scientific endeavor has been based from its early stages on inquiry, as an "act or an instance of seeking for truth, information, or knowledge; investigation; research; or a question or query." The root word, inquire, means "to ask for information, to make an investigation or search, to seek information or questioning." In ancient times, philosophers, particularly Socrates, were teaching their students by asking questions, guiding the student to finding the truth, or to realizing the limits of knowledge $[2,3]$.

In contrast, the ancient approach to teaching religious ideas was by means of myths and parables [4]. The major problems, such as the creation of the universe, the origins of life, death and the afterlife, have all been tackled through legendary stories and passed from one generation to the next $[5,6]$. Parables, as short allegorical stories, have been used to illustrate or teach some religious principles or spiritual lessons [ 7].

Over time pedagogical approaches have evolved, the teaching of science being strongly influenced by Jesuit educational models. As theological education was meant to deliver the ideas followers should know and respect, teachers were expected to give systematic instruction and deliver precise knowledge. With the mission to defend the religious core values and dogmas, the teachers were not supposed to encourage experiments, discussions or any deviations from the truth. However, despite the obvious focus of the monastic schools on theological instruction, advances in sciences, particularly in medicine and in astronomy (the latest in order to preserve the calendar and observation of religious holidays) did take place. Also, although much of the learning was contained to the confines of the monastery walls, knowledge did extend beyond the relatively isolated centers through travelers and pilgrims who would stay at the monasteries [8].

\section{BACKGROUND ON INQUIRY-BASED} INSTRUCTION

In modern times inquiry has evolved steadily [2], with a stronger impetuous in the early 1900 s due to 


\section{the Dialogue between Science and Theology}

the work of John Dewey [ 9, 10, 11], who considered that there was too much emphasis on the curriculum, on the subject matter to be taught, without enough emphasis on the student prior experience and on teaching them how to think. Dewey encouraged teachers of science to use inquiry as a teaching strategy in a few distinct steps: sensing perplexing situations, clarifying the problem, formulating a tentative hypothesis, testing the hypothesis, revising with rigorous tests, and acting on the solution. The teacher has a role of a facilitator and guide whereas the students should be actively involved, adding to their personal knowledge by addressing problems of interest, related to their experience and within their intellectual capability [12].

Later on, in the 1960s, Jerome S. Bruner emphasized the discovery methods of teaching, in which the learner is encouraged to discover new laws of nature and understand new concepts and ideas rather than being required to memorize the "truths" stated by the teacher or by the authoritative books [13, 14]. Various pedagogical approaches resulted, ranging from pure discovery methods, in which the student receives problems to solve with little or no guidance from the teacher, guided discovery methods, in which the student receives problems to solve but the teacher also provides hints, direction, coaching and feedback, to keep the student on track, and expository methods, in which the student is given the problem and, at the end, the correct answer [3]. Various studies [15, 16] showed that the guided discovery is generally more effective than both pure discovery and expository methods, as the students performed better in tests of immediate retention, delayed retention, and transfer to solving new problems.

The disputes about the impact of instructional guidance during teaching [17] have been ongoing for at least the past half-century. More recently, Kirschner et al. [18] argued that the evidence for the superiority of guided instruction can be explained in the context of our knowledge of human cognitive architecture, expert-novice differences, and cognitive load. Although unguided or minimally guided instructional approaches are very popular and intuitively appealing, they ignore both the structures that constitute human cognitive architecture and evidence from empirical studies over the past half-century that consistently indicate that minimally guided instruction is less effective and less efficient than instructional approaches that place a strong emphasis on guidance of the student learning process [17].

Arguing for inquiry-based learning (IBL) and problem-based learning (PBL), seen as guided instruction models, Hmelo-Silver et al. [19] present evidence demonstrating that PBL and IBL are powerful and effective models of learning. Far from being contrary to many of the principles of guided learning that Kirschner et al. [17] discussed, both PBL and IL employ scaffolding instruction extensively thereby reducing the cognitive load and allowing students to learn in complex domains. Scaffolding is the support given during the learning process which is tailored to the needs of the student with the intention of helping the student achieve his/her learning goals [18, 20]. Moreover, the IBL and PBL approaches to learning also address other important goals of education that include content knowledge, epistemic practices, and soft skills such as collaboration and self-directed learning [18].

The work of Hoffman et al. [21] showed, based on ten years of experience with PBL in a medical program, that graduates obtained higher performances on USMLEs and improved evaluations from residency program directors. The conclusion was that the inquiry approach better prepare graduates with knowledge and skills needed to practice within a complex health care system [20].

Later on, based on forty years of experience at the Medical School of McMaster University, where PBL was pioneered in 1969 [22], Alan Neville states [23]:

"Problem-based learning has swept the world of medical education since its introduction 40 years ago, leaving a trail of unanswered or partially answered questions about its benefits. The literature is replete with systematic reviews and meta-analyses, all of which have identified some common themes; however, heterogeneity in the definition of a 'problem-based learning curriculum' and its delivery, coupled with different outcome measurements, has produced divergent opinions. Proponents and detractors continue to dispute the merits of the cognitive foundation of a PBL approach, but, despite this, there is evidence that graduates of PBL curricula demonstrate equivalent or superior professional competencies compared with graduates of more traditional curricula."

Even more recently, Dolmans and Gijbels [24] agree that PBL can be characterized by: (i) learning in small groups; (ii) a teacher facilitating learning in the group; (iii) learning by means of problems that are first discussed in the group, and (iv) learning by means of self-study after which a discussion in the group follows. The problems in PBL are the trigger for the students to learn, ask questions, search for information and for self-study and, finally, arrive at and formulate a solution. The benefits of PBL reach 
beyond higher scores at medical examinations, improving students' social studying practices and enhancing student learning inside and outside the typical medical curriculum [25].

In a wider sense, going beyond the medical education and PBL, inquiry based learning has been also reviewed extensively. One such recent study, by Minner et al. [26] synthesizes findings from research conducted between 1984 and 2002 to address the research question: What is the impact of inquiry science instruction on $\mathrm{K}-12$ student outcomes? Based on the 138 analyzed studies, the authors find a clear, positive trend favoring inquiry-based instructional practices, particularly instruction that emphasizes student active thinking and drawing conclusions from data. It was concluded that instruction approaches that actively engage students in the education process through discovery and investigation are more likely to stimulate conceptual understanding than the strategies that rely on more passive techniques [25].

The discussions on improving instruction methods has left the academic debate and have entered the political agenda, as science education reform attracts significant attention around the world. Efforts in the USA [27, 28, 29], England [30], France [31], the European Union [32], Australia [33], etc. have been devoted to improving student performance, particularly due to government-established standards and/or national curricula. In this context, the National Research Council (NRC) of the USA described as "essential features of classroom inquiry" [28]:

"i) Learners are engaged by scientifically oriented questions.

ii) Learners give priority to evidence, which allows them to develop and evaluate explanations that address scientifically oriented questions.

iii) Learners formulate explanations from evidence to address scientifically oriented questions.

iv) Learners evaluate their explanations in light of alternative explanations, particularly those reflecting scientific understanding.

v) Learners communicate and justify their proposed explanations."

Additionally to the NRC requirements other skills are necessary for the effective learning of science in adolescent populations [34]. Such skills are: adaptability, complex communication/social skills, non-routine problem-solving skills, self-management/ self-development and systems thinking.

Given the central role of teacher training in the process of educational reform, some questions are of particular interest to science teacher educators: How does one prepare a teacher to utilize inquiry- based instruction? What barriers must be overcome to initiate such science education in the schools? What obstacles do teachers face when switching to the new pedagogical methods? [35] This emphasis on the learner needs to be matched by an equal focus on the teacher [36].

\section{INQUIRY-BASED INSTRUCTION IN VARIOUS}

\section{FIELDS}

In the previous section we mentioned how problem-based learning has been used extensively in medical schools across the USA and Canada. However, IBL concepts have been applied to other fields of knowledge. In particular, one such field is physics [37], pioneered by the group from University of Washington, but also chemistry and biology [38], electrical engineering [39, 40], and cognitive neuroscience [41], or even archeology [42].

A very useful IBL model, called the $5 \mathrm{Es}$, was introduced through the Biological Science Curriculum Study (BSCS), by a team lead by Roger Bybee $[43,44$, 45]. The five steps are:

(1) Engagement (Excite, stimulate the learner's curiosity)

(2) Exploration (Experiment to satisfy curiosity)

(3) Explanation (Show that you understand the concepts)

(4) Elaboration (Extend the new concepts into new areas)

(5) Evaluation (Check your knowledge)

The teacher appeals to the learners' prior knowledge and helps them become engaged in a new concept through the use of short activities that promote curiosity and elicit prior knowledge. The activity should make connections between past and present learning experiences, expose prior conceptions, and organize students' thinking toward the learning outcomes of current activities.

Physics education in Romania has also benefited from a project promoting IBL. The Romanian Physical Society has been involved in a project initiated in 2011 [46] by Cristian Hatu, with the aim to change the way physics is taught throughout secondary education, by stimulating students' active participation in the process of learning. Students are assisted by the teacher to discover the laws of physics and to understand the new concepts, after performing experiments and observations. During its different stages, the project has produced a methodological guide for the teachers as well as the psychopedagogical foundation of the new approach and has already trained to use the new methods over 1300 teachers. Moreover, various materials have 


\section{the Dialogue between Science and Theology}

been prepared to assist teachers in using the new approach: short videos presenting experiments and demonstrations with common, everyday objects, guidelines regarding class management, higher complexity tasks for students with high intellectual potential, items for student evaluation for a part of the learning units etc. Numerous examples of such materials have been uploaded on the webpage of the project [46].

\section{IS IBL SUITED FOR THEOLOGY EDUCATION?}

Inquiry-based learning requires that the learner draws on his own past experience and existing knowledge to discover facts and relationships and new truths. Students interact with the world by exploring and manipulating objects, wrestling with questions and controversies, or performing experiments. As a result, students may be more likely to remember concepts and knowledge discovered on their own (in contrast to being given the answer by the teacher). But is such an approach valuable in teaching religious concepts?

Why this interest in inquiry? Teaching religion is not trivial, particularly as many of its concepts are pretty abstract and difficult to grasp by students. In addition, teachers of religion are often given the mission to 'translate' the concepts, to make them more familiar for adherents. It remains challenging for an educator to translate concepts into behavior, and large ideas into social conduct.

Being convinced that any kind of education can benefit from such new methods of teaching, we argue, in the fallowing, that inquiry-based instruction may be an effective technique even when tackling theology education.

To answer the questions above we can return to the 5 Es applied initially to teaching biology. Is Engagement needed in teaching religion as it is in teaching science? The answer is, most likely, positive, as the students learn more effectively when their interest is triggered by an interesting and exciting problem.

What is a trigger and what could be effective triggers in teaching religion? A trigger could be anything, from a simple word, an image, a symbol, a short movie or a particular gesture, anything that can stimulate the student's curiosity for the theme. For instance, before starting a discussion on how heaven is perceived in Christianity, Islam and Judaism, it may be useful to display a few relevant pictures, particularly renaissance paintings and old orthodox frescos on that theme. Similarly, a display of two paintings depicting the Judgement Day could generate interest from the students more effectively than a typical, traditional lecture about the differences between Catholics and Orthodox Christians. Pictures or little movies with atrocities caused in the name of religion could trigger an emotional reaction and openness for a lecture on respect for all faiths. Scientific illustrations, such as the echography of the fetus or gene sections, could trigger interest and vivid discussions on abortion and on genetic engineering or gene therapy.

The classes can also start by provoking the students with cognitive conflicts [47], addressing known misconceptions. Cognitive conflicts can be imagined not just in Science but also in Theology, as the religious educator also has to deal with preconceptions or misconceptions. Typically, examples of conflicts that could trigger the student interest with respect to learning theological concepts are those regarding proving wrong some of their prior beliefs (particularly related to old superstitions and practices in contradiction with religious principles) and those related to the lack of alignment or harmony between one's words and deeds. Fighting pre- or misconceptions is, many times, teaching against wrong conduct or heresy.

The second step, Exploration, is typical for science. Can it be relevant for teaching theology? Although experimenting is the key attribute of the scientist it should not be disregarded when teaching religion. In the end, religion paves the spiritual way of approaching Divinity and such path can benefit from landmarks, from guidance along the way. For the students, reading or hearing about the Path is not enough. They need to experiment themselves, through prayer and meditation: 'Then He spoke a parable to them, that men always ought to pray and not lose heart.' Luke 18:1 [48]. And, through prayer and meditation, they get a better understanding of their own way: 'But let a man examine himself, and so let him eat of the bread and drink of the cup.' 1 Corinthians 11:28, 'I meditate within my heart, And my spirit makes diligent search.' Psalm 77:6 [48].

If in science the students explore the reality around them, in religion they experience and discover their own spiritual self by praying and meditation as well as by acting in the real world:

' 12 Because I delivered the poor who cried out, The fatherless and the one who had no helper. 13 The blessing of a perishing man came upon me, And I caused the widow's heart to sing for joy. 14 I put on righteousness, and it clothed me; My justice was like a robe and a turban. 15 I was eyes to the blind, And I was feet to the lame. 16 I was a father to the poor, And I searched out the case that I did not know. 17 I broke 
the fangs of the wicked, And plucked the victim from his teeth.' (Job 29:12-17 [48].)

In science, the teacher gives the students educational materials and guides their experiments and observations; in religion the teacher follows the students through their search and guides them when they encounter obstacles. With right guidance from an educator, the students may discover truths that were always there, inside their soul. Similar patterns are used in psychoanalysis and psychological therapy, matrimonial counseling, and various cases of social conflict. Through inquiry technics people are brought to seeing the real problem and the solution to it, which in fact lies inside themselves. Ultimately, is up to them to act and solve that problem.

Embracing someone else's thoughts and conduct is not an issue easy to deal with; we can see that every day at parents-child relation and its failure in most cases. 'Acceptance involves undefended exposure to thoughts, feelings, and bodily sensations as they are directly experienced to be.' [49] It is important to understand the stages the students go through during their experimenting, that the person have to let go of controlling private events and expose themselves to these trials without the use of safety nets. In religious education students are supposed to give up more, being asked to abandon their old mind and to be open for discovering new truths:

' 9 Do not lie to one another, since you have put off the old man with his deeds, 10 and have put on the new man who is renewed in knowledge according to the image of Him who created him' (Colossians 3:9-10 [48].)

In the third and fourth steps, Explanation and Elaboration, the students are supposed to show that they understand the concepts and then, use them extend their use in other contexts. In the learning process they ought to do more than just reproduce the knowledge. They ought to give in to the profound meaning of the teachings.

One way to guide the students through these stages is to present new images and/or parables and ask them to draw parallels with the initial ones. For instance, when discussing religious symbols and/vs. objects of adoration, one can give additional examples to the initial ones and check whether the students can explain and then extend their knowledge to adjacent topics.

One example of teaching by inquiry could be provided by the parable of the adulteress. The 'students' were the scribes and Pharisees; they were not offered an answer but another question to ask themselves:
So when they continued asking $\mathrm{Him}$, He raised Himself up and said to them, 'He who is without sin among you, let him throw a stone at her first.' (John 8:7 [48].)

The 'students' had to search in their own souls and discover the answer. By using such challenging, selfawareness ways of teaching, student misconceptions and preconceptions can be dispelled, leaving room for a new way of thinking.

Unlike teachers, educators [50] have to produce positive reactions into the minds and souls of the students so that they will not only understand and embrace the new concepts, but they become able to promote them further. It is a great challenge for every religious teacher to transform dogma into behavior, to convert knowledge into social conduct, which have to be self-inflicted, believed and not only trusted or accepted [51]. Religion has a role in providing responses to those experiences which lack interpretability, to create strong, long-lasting emotions that lead to a moral social conduct. Religion is a 'vehicle which enables participants to give form and meaning to their experiences' [52]. This may be the Elaboration step for religious teaching as students are impelled to extend the new concepts acquired into their lives, to formulate a particular path for applying the ideas they embraced.

The last step, the Evaluation is required in any formal education process, as it allows the instructor to verify whether the student has acquired the targeted competences. Therefore, religious education can make no exception, having to rely on evaluation, for any religion has the ways and characteristic means.

How should this evaluation take place? In the case of religion, showing knowledge is not enough. The student is expected to also show compassion and advancement on his spiritual path: 'Examine me, O LORD, and prove me; Try my mind and my heart.' (Psalm 26:2 [48]).

Students are supposed to be appraised for becoming better persons, for applying in the everyday life the principles that they have learned in class. Additional to the regular, educational tools the religious teacher has an extra way to examine the students. The confession is, probably, the most powerful method of evaluation, as it allows going beyond the classroom experience and reach into the deeper beliefs and emotions of the student.

In conclusion of this section, we argued that, to various extent, all the 5 Es steps formulated by Bybee [43] have some relevance to religious instruction.

VI. IS STORY-TELLING USEFUL FOR SCIENCE EDUCATION? 


\section{the Dialogue between Science and Theology}

We argue in the following that knowing how the scientist think and work, how they lived and came to understand or discover knowledge, can have a positive role on students as future scholars.

For instance, learning about celestial mechanics in a science class can be too abstract and challenging to students. Inserting stories about the history of these concepts may give the students an overall idea of how advancement of knowledge actually takes place, how, sometimes, novel theories are not easily accepted. The evolution of common thought regarding the celestial motion brings together science and philosophy and even religion.

Ancient Indian cosmology describes, around the 15th - 12th century B.C.E., a universe that is created, destroyed, and re-created in an eternally repetitive series of cycle [53]. Later on, the Greek philosopher Aristotle in the 4 th century B.C.E. and the RomanEgyptian mathematician and astronomer Ptolemy, in the 2 nd century C.E., described a geocentric model, in which the planets and the rest of the universe orbit about a stationary Earth. In contrast, in the zrd century B.C.E. the Greek astronomer and mathematician Aristarchus of Samos presented a heliocentric model, placing the Sun, not the Earth, at the center of the known universe. His ideas were generally rejected in favor of the geocentric theories of Aristotle and Ptolemy until they were successfully revived nearly 1800 years later by Copernicus.

Such stories of correct theories being overlooked in favor of wrong ones are not singular. Another example may be the wave theory of light published in 1690 by the Dutch physicist Christiaan Huygens [54], which was dominated by the Isaac Newton's corpuscular theory made public in 1704 [55]. For more than 100 years, the corpuscular theory was favored over the wave theory, partly because of Newton's great prestige and partly because not enough experimental evidence existed to provide an adequate basis of comparison between the two models. When light interference, diffraction and polarization experiments were performed the wave theory became the dominant theory of the nature of light.

Going back to celestial mechanics, it is useful to present a little history to illustrate how scientific progress takes place. We follow Thomas Kuhn's arguments that periods of conceptual continuity in normal science, characterized by development by accumulation, are interrupted by periods of revolutionary science, when the discovery of 'anomalies' lead to revolutions in science and to new paradigms [56]. Tycho Brahe, a Danish astronomer who tried to reconcile the Ptolemaic and Copernican models of was recognized for his precise measurements of planetary motion. Although he had at hand massive amounts of astronomical data, he advocated for a system with an immobile Earth. According to Tycho Brahe, the idea of a rotating and revolving Earth would be 'in violation not only of all physical truth but also of the authority of Holy Scripture, which ought to be paramount' [57].

Johannes Kepler, a German mathematician and astronomer, who for a short time was Tycho Brahe's assistant, did not succeed to convince his mentor to embrace the Copernican model. After Tycho Brahe's death, inheriting the vast collection of astronomical observations, particularly on the motion of Mars, Kepler was able to draw three laws that described the planetary motion: the law of elliptical orbits, the law of equal areas and the law of periods $[58,59]$.

According to Kuhn [56], 'individual scientists embrace a new paradigm for all sorts of reasons and usually for several at once.' Some of these reasons, for instance, the worship of the Sun that made Kepler a Copernican-lie outside the apparent sphere of science entirely [56, 60]. Much of Kepler's enthusiasm for the Copernican system stemmed from his theological convictions about the connection between the physical and the spiritual; the universe being an image of God, with the Sun corresponding to the Father, the stellar sphere to the Son, and the space in-between to the Holy Spirit [61].

Finally, Isaac Newton, an English physicist and mathematician, was able to make a step even further, deriving all three of Kepler's laws by means of one single law of universal gravitation [62]. He was able to make such a huge step forward due to his knowledge of the mechanical laws of motion, which he presented to the Royal Society in 1686, before the publication of the 'Principia' one year later. Such stories of science history are relevant to show that the development of science means long times of accumulation interrupted by revolutions, when new paradigms are shaped, taking over the previous theories.

The advancement of science may sometimes be a bumpy road. Robert Hooke, another English physicist, accused Newton of plagiarism, claiming that the idea of the decrease of gravity by the square of the distance between the bodies was taken from him. Newton did accept and acknowledge, in all editions of the 'Principia,' that Hooke (and others) had separately considered the inverse square law and the centrifugal/ centripetal effects to discuss planetary motion. However, there is a long distance between a truth that is glimpsed and a truth that is demonstrated [63]. 
Thus, the importance of giving credit to the prior work on the topic was well known long before the modern ethical standards in conducting research [64].

One last point that is worth making is on the role of serendipity in research discoveries. Serendipity is the occurrence and development of events by chance in a satisfactory or beneficial way. Typically, by 'chance' we understand that the event takes place in the absence of any obvious project (randomly or accidentally), which is not relevant to any present need, or in which the cause is unknown. Under these circumstances, it should be emphasized that serendipity in scientific research has an important characteristic: discoveries are made by scholars able to make creative connections, based on a deeper understanding of the problem, where others are subject to only astonishment. It is attributed to Louis Pasteur that 'Chance favors only the prepared mind' [65]. Although it is estimated that between 33\% and $50 \%$ of all scientific discoveries are unexpected, however it is believed that [65]:

'Scientists are not passive recipients of the unexpected; rather, they actively create the conditions for discovering the unexpected and have a robust mental toolkit that makes discovery possible.'

To give an example of the role of chance in scientific discovery we can return to Newton's discovery of gravity. Due to some infectious disease, Newton was sitting in his yard when he noticed an apple fall from a tree [66]. The apple fell straight down, perpendicular to the ground, never upward or off to a side, which prompted Newton to conclude that it was a property of all matter to interact with attractive forces along the direction of their centers. It was another 20 years before Newton published his detailed theory of gravity, but he later visited the tree that helped him provoke the idea [67].

In summary of this section, we argued that science teaching can benefit from the history of scientific discoveries. The students may more easily see the pattern every scientist had in his development; one that can become their own pattern of discovery. Acquiring only the knowledge of the predecessors is not enough, as it does not stimulate creativity and independent thinking. On the contrary, evaluating the process in which the knowledge was forged, may lead to new discoveries and further inquiry. Moreover, the students may learn about the role of chance, the importance of ethical conduct and, through anecdotal stories about the lives of the scientists may develop role models for their entire career and, overall, classes may be more fun to attend.

\section{CONCLUSION}

We argued that inquiry methods can be used to stir interest and make teaching more enjoyable and more effective not just in science instruction but also in theology education. Fishermen in Bible times as well as today need not to be given fish and be fed for a day; they need to be taught how to fish and feed themselves for a lifetime. Bringing people in a state of self-involvement with the source of knowledge is a better method of teaching for both science and theology.

Religious education has used some kinds of inquiry methods for a long time, as parables and symbolic stories were at the core of theological education for all faiths. We went further and analyzed whether Bybee's $5 \mathrm{E}$ steps could be extended to theology education. We concluded that the first and the last steps (Engagement and Evaluation) should be common to any kind of teaching, as stimulating the students' curiosity and checking the knowledge acquired cannot be separated from the training process. While the third and fourth steps, Explanation and Elaboration, are more easily adaptable to religious education, the most challenging step is Exploration, as experimenting to satisfy curiosity has not been widely regarded as characteristic to religious endeavors. However, as the students are supposed to find their way to Divinity, pointing to the landmarks that can guide their way may be useful for them. If in science the students explore the reality around them, in religion they experience and discover their own spiritual self by praying and meditation as well as by acting in the real world.

In turn, we also argued that the story-telling, typical for teaching religion, can be used in science education. Accumulating knowledge is not enough; students need to develop critical and creative thinking. Listening to stories about scientific discovery could teach them lessons that, later on, could support them in fighting future obstacles. Knowing that chance may also play a role, creating opportunities, but only those prepared to seize such occasions can benefit, may prove important for the overall education of the adult. Moral values and the emphasis on ethical conduct is key to the individual, as a principled member of the community, and beneficial to society as a whole. Moreover, the anecdotal stories about the lives of the scientists may help students in developing role models for their entire career and make classes more enjoyable.

ACKNOWLEDGMENTS

The authors are grateful to dr. Cristian Hatu and 


\section{the Dialogue between Science and Theology}

dr. Cristina Miron for useful discussions. The financial support of the Romanian-American Foundation as well as the generous sponsorship form BRD - Groupe Société Générale and OMV - Petrom is thankfully acknowledged.

\section{DECLARATION OF CONFLICTING INTERESTS}

The authors declared no conflicts of interests with respect to the authorship and/or publication of this article.

\section{REFERENCES}

[1] M.A. Gîrțu and C.T. Ciocan, "Scientific Consensus, Public Perception and Religious Beliefs - A Case Study on Nutrition" in Dialogo 2014, Proceedings of the 1st Virtual Conference on the Dialogue between Science and Theology. Cosmology, Life \& Anthropology, Edts: C.T. Ciocan and A. Lieskovsky, EDIS - Publishing Institution of the University of Zilina, 2014, pp. 70-75.

[2] L.H. Barrow, "A brief History of Inquiry: From Dewey to Standards", Journal of Science Teaching Education 17 (2006) 265-278.

[3] R.E. Mayer, "Should There Be a Three-Strikes Rule Against Pure Discovery Learning? The Case for Guided Methods of Instruction", American Psychologist 59 (2004) 14-19.

[4] G.H. Betts, "How to teach Religion: Principles and Methods," The Floating Press, 2009.

[5] M. Eliade, "Myths, Dreams, and Mysteries: The Encounter between Contemporary Faiths and Archaic Realities," Harper and Row Publishers, 1961.

[6] M. Eliade, "Myth and Reality (Religious Traditions of the World)," Harper and Row Publishers, 1963.

[7] D.G. Gowler, "What are they saying about the Parables," Paulist Press, 2000.

[8] D.C. Lindberg, "The Beginnings of Western Science," University of Chicago Press, 2007.

[9] J. Dewey, „The relation of theory to practice in the education of teachers." in C. A. McMurry (Ed.), National society for the study of education, Yearbook III, Part I (pp. 9-29). Bloomington, IN: Public School Publishing, 1904.

[10] J. Dewey, „Science as subject-matter and as method" Science 31, (1910) 121-127.

[11] J. Dewey „Method in science teaching” The Science Quarterly 1, (1916) 3-9.

[12] J. Dewey, Experience and education. New York: Collier Books, 1938.

[13] J.S. Bruner, ,The act of discovery.” Harvard Educational Review 31 (1961) 21-32.

[14] J.S. Brunner, "Toward a Theory of Instruction", Harvard University Press, 1966.

[15] J.E. Kittel, "An experimental study of the effect of external direction during learning on transfer and retention of principles". Journal of Educational Psychology, 48, (1957) 391-405.

[16] R.M. Gagne and L.T. Brown, „Some factors in the programming of conceptual learning." Journal of Experimental Psychology 62 (1961) 313-321.

[17] L.S. Shulman, and E.R. Keisler, Learning by discovery. Chicago: Rand McNally, 1966.

[18] P.A. Kirschner, J. Sweller, and R.E. Clark, "Why minimal guidance during instruction does not work: An analysis of the failure of constructivist, discovery, problem-based, experiential, and inquiry-based teaching." Educational Psychologist 41 (2006) 75-86.

[19] C.E. Hmelo-Silver, R.G. Duncan, and C.A. Chinn, „Scaffolding and Achievement in Problem-Based and Inquiry Learning: A Response to Kirschner, Sweller, and Clark (2006)," Educational Psychologist 42 (2007) 99-107.

[20] A. Ninio and J. Bruner, „The achievement and antecedents of labelling." Journal of Child Language 5 (1978) 1-15.

[21] K. Hoffman, M. Hosokawa, R. Blake Jr., L. Headrick, and G. Johnson, „Problem-Based Learning Outcomes: Ten Years of Experience at the University of MissouriColumbia School of Medicine," Academic Medicine, 81 (2006) 617-625.

[22] A.J. Neville and G.R. Norman, ,PBL in the undergraduate MD program at McMaster University: three iterations in three decades." Academic Medicine 82 (2007) 370-374.

[23] A.J. Neville, "Problem-Based Learning and Medical Education Forty Years On: A Review of Its Effects on Knowledge and Clinical Performance," Medical Principles and Practice 18 (2009) 1-9.

[24] D. Dolmans and D. Gijbels, „Research on problembased learning: future challenges" Medical Education 47 (2013) 214-218.

[25] P. Orsmond and R. Zvauya, „Community of learners: charting learning in first year graduate entry medical students during problem-based learning (PBL) study" Advances in Health Science Education 20 (2015) 479 497.

[26] D.D. Minner, A. Jurist Levy, J. Century, „Inquiry-Based Science Instruction-What Is It and Does It Matter? Results from a Research Synthesis Years 1984 to 2002" Journal of Research in Science Teaching 46 (2009) 1-24.

[27] AAAS (American Association for the Advancement of Science) Benchmarks for science literacy: Project 2061. New York: Oxford University Press, 1993.

[28] National Research Council, „National science education standards." Washington, DC: National Academy Press, 1996.

[29] National Research Council, „Inquiry and the national science education standards." Washington, DC: National Academy Press, 2000. 
the Dialogue between Science and Theology

[30] Department for Education and Employment. "The national curriculum for England," London: Department for Education and Employment, 1992. Retrieved from http:/ /curriculum.qcda.gov.uk/

[31] G. Chaprak, "La main à la pâte. Histoire des sciences à l'école primaire" Flammarion, 1998.

[32] European Commission. „Science education now: A renewed pedagogy for the future of Europe," Brussels, European Commission, 2007.

[33] D. Goodrum and L. Rennie, „Australian school science education national action plan 2008-2012" Commonwealth of Australia, vol. 1, 2007.

[34] E.M. Anderman, G.M. Sinatra and D.L. Gray, „The challenges of teaching and learning about science in the twenty-first century: exploring the abilities and constraints of adolescent learners," Studies in Science Education 48 (2012) 89-117.

[35] R.D. Anderson, „Reforming science teaching: What research says about inquiry." Journal of Science Teacher Education, 13 (2002) 1-12.

[36] B.R. Brand and S.J. Moore, "Enhancing Teachers' Application of Inquiry-Based Strategies Using a Constructivist Sociocultural Professional Development Model," International Journal of Science Education 33 (2011) 889-913.

[37] L.C. McDermott \& the Physics Education Group at the University of Washington Physics by Inquiry, John Wiley, New York, 1996.

[38] T. Eberlein, J. Kampmeier, V. Minderhout, R.S. Moog, T. Platt, P. Varma-Nelson, and H.B. White, "Pedagogies of Engagement in Science - A Comparison of PBL, POGIL, AND PLTL," Biochemistry and Molecular Biology Education 36 (2008) 262-273.

[39] J.C. Perrenet, P.A.J. Bouhuijs, and J.G.M.M. Smits, "The Suitability of Problem-based Learning for Engineering Education: theory and practice." Teaching in Higher Education 5 (2000) 345-358.

[40] N.J. Powell, P.J. Hicks, W.S. Truscott, B. Canavan, "Problems in the Semiconductor Industry: Teaching Design and Implementation of VLSI Systems using Problem-Based Learning", 6th European Workshop on Microelectronics Education, Stockholm, Sweden, 2006, pp. 1-4.

[41] T. Stafford, „A fire to be lighted: a case-study in enquirybased learning," Practice and Evidence of Scholarship of Teaching and Learning in Higher Education 3, (2008) 20-42.

[42] E.-L.H. McGuire, „Students and their digs: Enquiry based learning in level-one Archaeology," Practice and Evidence of Scholarship of Teaching and Learning in Higher Education 3, (2008) 84-101.

[43] R.W. Bybee, et al., Science and technology education for the elementary years: Frameworks for curriculum and instruction. Washington, D.C.: The National Center for Improving Instruction, 1989.

[44] R.W. Bybee,. Science curriculum reform in the United States. Washington, DC: National Academy Press, 2003.

[45] R.W. Bybee, J.A. Taylor, A. Gardner, P. Van Scotter, J. Carlson Powell, A. Westbrook, and N. Landes, "The BSCS 5E Instructional Model: Origins, Effectiveness, and Applications," BSCS Colorado Springs, 2006.

[46] Romanian Physical Society, The reform of the physics education in Romania through inquiry-based learning, www.srfizica.ro/rpfip

[47] J.A. Rowell and C.J. Dawson, "Cognitive conflict: It's Nature and Use in the Teaching of Science," Research in Science education, 9 (1979) 169-175.

[48] New King James Version Study Bible, Thomas Nelson Inc., 1982.

[49] S.C. Hayes, V.M. Follette, and M.M. Linehan (editors), Mindfulness and acceptance: expanding the cognitivebehavioral tradition. New York: The Guilford Press, 2004, p. 21

[50] B. Stremba, C.A. Bisson (editors). Teaching adventure education Theory: best practices. United States: Human Kinetics, 2009.

[51] C.T. Ciocan, "Ludic role of religious rituals" in Dialogo 2015, Proceedings of the 2nd Virtual Conference on the Dialogue between Science and Theology. Edts: C.T. Ciocan and S. Badura, EDIS - Publishing Institution of the University of Zilina, 2015, in press.

[52] J. Bowker (edit.). The Oxford Dictionary of World Religions. New York: Oxford University Press, 1997, p. 369.

[53] A. Zimmerman Jones, "String Theory for Dummies." John Wiley \& Sons, 2009.

[54] C. Huygens, "Traité de la lumiere." Leiden, Netherlands: Pieter van der Aa, 1690.

[55] I. Newton, "Opticks: or, a treatise of the reflexions, refractions, inflexions and colours of light. Also two treatises of the species and magnitude of curvilinear figures." (Originally published in London in 1704.) with commentary by Nicholas Humez (Octavo ed.), Palo Alto, California, 1998.

[56] T.S. Kuhn, "The Structure of Scientific Revolutions," University of Chicago, 1962.

[57] J. Repcheck "Copernicus's Secret: How the Scientific Revolution Began." Simon \& Schuster, 2008.

[58] J. Kepler, "New Astronomy," translated by W.H. Donahue, Cambridge: Cambridge University. Press, 1992.

[59] J. Kepler, "Epitome of Copernican Astronomy and harmonies of the World," Great Minds Series, Prometheus Books Publishers, 1995.

[60] E. A. Burtt, "The Metaphysical Foundations of Modern Physical Science,” rev. ed. New York, 1932. 


\section{the Dialogue between Science and Theology}

[61] P. Barker and B.R. Goldstein. "Theological Foundations of Kepler's Astronomy," Osiris, 16 (2001) 88-113.

[62] Isaac Newton "Philosophiae Naturalis Principia Mathematica." 3rd Edition (1726) with Variant Readings, A. Koyre, B.I. Cohen and A. Whitman (eds.), Harvard University Press, Cambridge, Massachusetts, 1972.

[63] W.W. Rouse Ball, "An Essay on Newton's 'Principia"” London and New York: Macmillan, 1893.

[64] Committee on Science, Engineering, and Public Policy, National Academy of Science, National Academy of Engineering, and Institute of Medicine of the National Academies. "On being a scientist: A guide to responsible conduct in research," 3rd ed., National Academies Press, 2009.

[65] K. Dunbar and J. Fugelsang, "Causal thinking in science: How scientists and students interpret the unexpected." In M.E. Gorman, R.D. Tweney, D. Gooding \& A. Kincannon (Eds.), Scientific and Technical Thinking (pp. 57-79). Mahwah, NJ: Lawrence Erlbaum Associates, 2005.

[66] R. Gaughan, “Accidental Genius: The World's Greatest By-Chance Discoveries.” Metro Books, 2010.

[67] R.M. Roberts, "Serendipity: Accidental Discoveries in Science.” John Wiley \& Sons, Inc., New York, 1989.

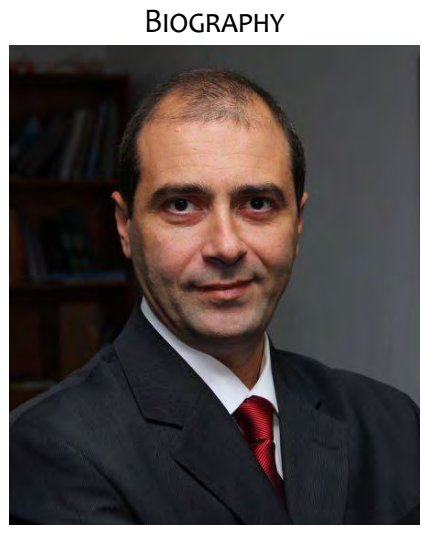

Mihai A. Gîrțu is Professor of Physics at Ovidius University of Constanța, Romania. A graduate of the University of Bucharest with an M.Eng. degree in Applied Physics, he received the Ph.D. degree in Physics from the Ohio State University, USA. His research interests focus on molecular modeling and simulations of materials with applications in organic electronics and hybrid photovoltaics, molecular magnetism, photocatalytic degradation, and, more recently, in biomedical sciences. He is a member of $\Phi K \Phi$ and $\Sigma X$ honor societies, and a recipient of the In hoc signo vinces award of the Romanian National
Research Council. He has experience in research policy making and research management, gained while serving as vice-president of the Romanian University Research Council (CNCSIS), as well as in higher education funding, acquired in the course of his term in the Romanian Council for Higher Education Funding (CNFIS). Presently he serves as vice-rector for international relations of Ovidius University of Constanța.

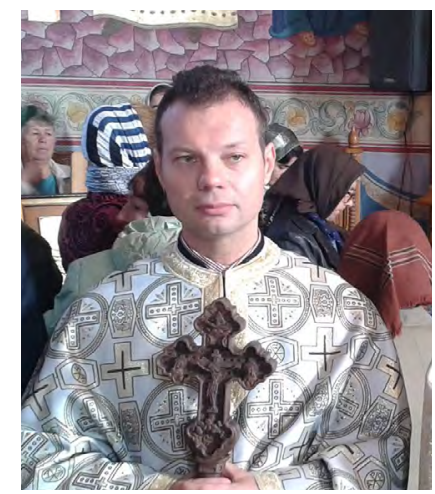

Ciocan Tudor Cosmin, born in Constanta/Romania in 1977, I have attended several theological and psychological schools (BA, MB, PhD), obtained my PhD in Missiology and Doctrinal Theology in 2010. I was ordained as orthodox priest in 2002. Highschool teacher from 1998, then Professor assistant and Lecturer from 2012, I have written more than 30 papers on theology and psychology, along with 4 single author books in the past two decades.

In 2013 I started a multidisciplinary program aiming to engage scholars from different files into friendly and academic debates with theology and in the same year a Research Center was founded in Ovidius University with researchers from 11 fields. in lest then 1 year I manage to gather people from around the globe around this idea and so we have started Dialogo Conferences project. In 2014 I received a Fulbright scholarship and I spent the summer California and 4 other States in USA, gathering data and understanding how religious pluralism is possible at a high level of involvement; in the same time I made friends from many different countries and religions that are now involved in this project or another, helping in his endeavor. 